\title{
Antidiabetic Activity of Calcium Bentonite in Alloxan Monohydrate- induced Diabetic Wistar Rat Models
}

\author{
Galuh Alviana, ${ }^{1}$ Hendro Sudjono Yuwono, ${ }^{2}$ Nova Sylviana ${ }^{3}$ \\ ${ }^{1}$ Faculty of Medicine Universitas Padjadjaran, ${ }^{2}$ Department of Surgery Faculty of Medicine \\ Universitas Padjadjaran/Dr. Hasan Sadikin General Hospital, Bandung, ${ }^{3}$ Department of \\ Physiology, Faculty of Medicine Universitas Padjadjaran
}

\begin{abstract}
Background: Calcium bentonite is a natural clay that has the ability to absorb toxins and metabolite excess substances and often referred to as healing clay because it is used traditionally. This study aimed to determine the ability of local calcium bentonite to absorp high blood glucose..

Methods: This study was an experimental study using 20 female Wistar rats and divided into two groups consisting of Group I (control group, $n=10$ ) and Group II (calcium bentonite group, $n=10$ ). Diabetes in rats was induced by alloxan monohydrate $150 \mathrm{mg} / \mathrm{kg}$ body weight intraperitoneally. Examination of blood glucose was performed three times; in the beginning of study, 72 hours after alloxan monohydrate induction, and four days after the given interventions. Blood glucose levels in mean values were analyzed using t-independent test. Statistically significance was considered when $\mathrm{p}<0.05$.

Results: Oral calcium bentonite of $1 \mathrm{~g} / \mathrm{kg}$ body weight significantly lowered blood glucose level relatively to the control group with average value of $131.30 \mathrm{mg} / \mathrm{dl}(\mathrm{p}=0.01)$.

Conclusions: Calcium bentonite significantly lowers blood glucose levels. [AMJ.2015;2(3):359-62]
\end{abstract}

Keywords: Calcium Bentonite, diabetes mellitus, hyperglycemia, traditional medicine, wistar rats

\section{Introduction}

Calcium bentonite (ca-bentonite) is a type of natural clay which has the ability to absorb water and toxic substances and referred to as one of healing clays. ${ }^{1}$ In Indonesia, cabentonite is traditionally used as a detoxifying agent in the gut, traumatic wounds, and skin disorders. ${ }^{1,2}$

Previous study showed that the cabentonite has the ability to absorb blood ureum and creatinine in rats with acute renal failure and reduce high blood cholesterol level on rat. ${ }^{3-6}$ This study aimed to determine the ability of local ca-bentonite to absorp high blood glucose.

\section{Methods}

A total of 20 adult female Wistar rats weighing 150-250g obtained from Pusat Penelitian Antar Universitas (PPAU), Institute of
Technology Bandung, were used in this study. The rats were housed at the animal laboratory of the Department of Pharmacology, Faculty of Medicine, Univeristas Padjadjaran, Bandung, under standard condition of food and drinking water. The study protocols and animal care procedure were approved by the Health Research Ethic Committee of Faculty of Medicine Universitas Padjadjaran.

Ca-bentonite was obtained from Chemistry Laboratory Faculty of Mathematics and Sciences Education, Universitas Pendidikan Indonesia. Rats were given $1 \mathrm{~g} / \mathrm{kg}$ body weight of ca-bentonite, the same dosage which can reduce excessive blood ureum and creatininein rats with acute renal failure from previous studiy. ${ }^{3}$ Ca-bentonite weighs 0.25 gram was diluted with aquadest as much as 5 $\mathrm{mL}$ and ready to be given orally once daily for 3 days, starting 72 hrs after alloxan induction. Alloxan monohydrate from Sigma, Singapore, is used as much as $150 \mathrm{mg} / \mathrm{kg}$ body weight dissolved in $10 \mathrm{cc}$ aquadest to be injected

Correspondence: Galuh Alviana, Faculty of Medicine, Universitas Padjadjaran, Jalan Raya Bandung-Sumedang Km.21, Jatinangor, Sumedang, Indonesia, Phone: +62 8122156389 Email: galuh.alviana@gmail.com 
Table 1 Measurement of Blood Glucose Levels

\begin{tabular}{cccc}
\hline Group & Intervention & Measurement** & Blood Glucose Level (mg/dl)\# \\
\hline$I^{*}$ & Aquadest $5 \mathrm{ml}$ & Day 0 & $100.60 \pm 3.406$ \\
& & Day 3 & $291.70 \pm 62.029$ \\
& & Day 7 & $291.20 \pm 155.108 \# \#$ \\
\multirow{2}{*}{$\mathrm{II}^{*}$} & Calcium bentonite $1 \mathrm{~g} / \mathrm{kg} \mathrm{BW}$ & Day 0 & $103.60 \pm 8.303$ \\
& & Day 3 & $434.40 \pm 113.416$ \\
& & Day 7 & $131.30 \pm 46.166 \# \#$ \\
\hline
\end{tabular}

Note: ${ }^{*} \mathrm{n}=10$

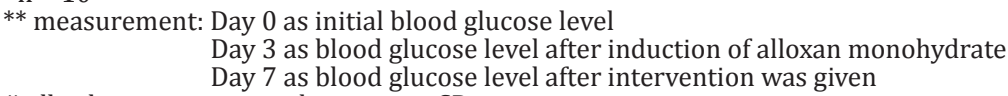

** measurement: Day 0 as initial blood glucose level

Day 3 as blood glucose level after induction of alloxan monohydrate

Day 7 as blood glucose level after intervention was given

\# all values are expressed as mean \pm SD

$\# \# \mathrm{p}=0.01$ and was considered statistically significant as compared to after treatment of their respective group

intraperitoneally. ${ }^{7-9}$

The experimental animals were randomly allocated into 2 groups, Group I was given aquadest as control group and Group II was given ca-bentonite as intervention, referred to as ca-bentonite group. Before measuring the blood glucose, the rats were fasting for 18 hours. Venous blood was taken from cutting of the tail end and the blood was dropped into the glucosemeter..$^{7-9}$ The results will appear in 10 seconds. Blood glucose measurement was performed three times in each groups: at the time after acclimatization as the initial blood glucose levels in normal rats (Day 0 ), 72 hours after alloxan monohydrate induction (Day 3 ), and four days after the interventions was given (Day 7).7,9

Blood glucose levels were analyzed using t-independent test. Statistically significance was considered when $\mathrm{p}<0.05$.

\section{Results}

The anti-diabetic effect of oral administration of aquadest and ca-bentonite on rats glucose level were shown in Table 1. This study revealed that 72 hours after induction of alloxan monohydrate produced a hyperglycemia state (Day 3), and 3 day oralca-bentonite $1 \mathrm{~g} / \mathrm{kg}$ treatment resulted in a significant decrease of blood glucose level in the model of alloxan-

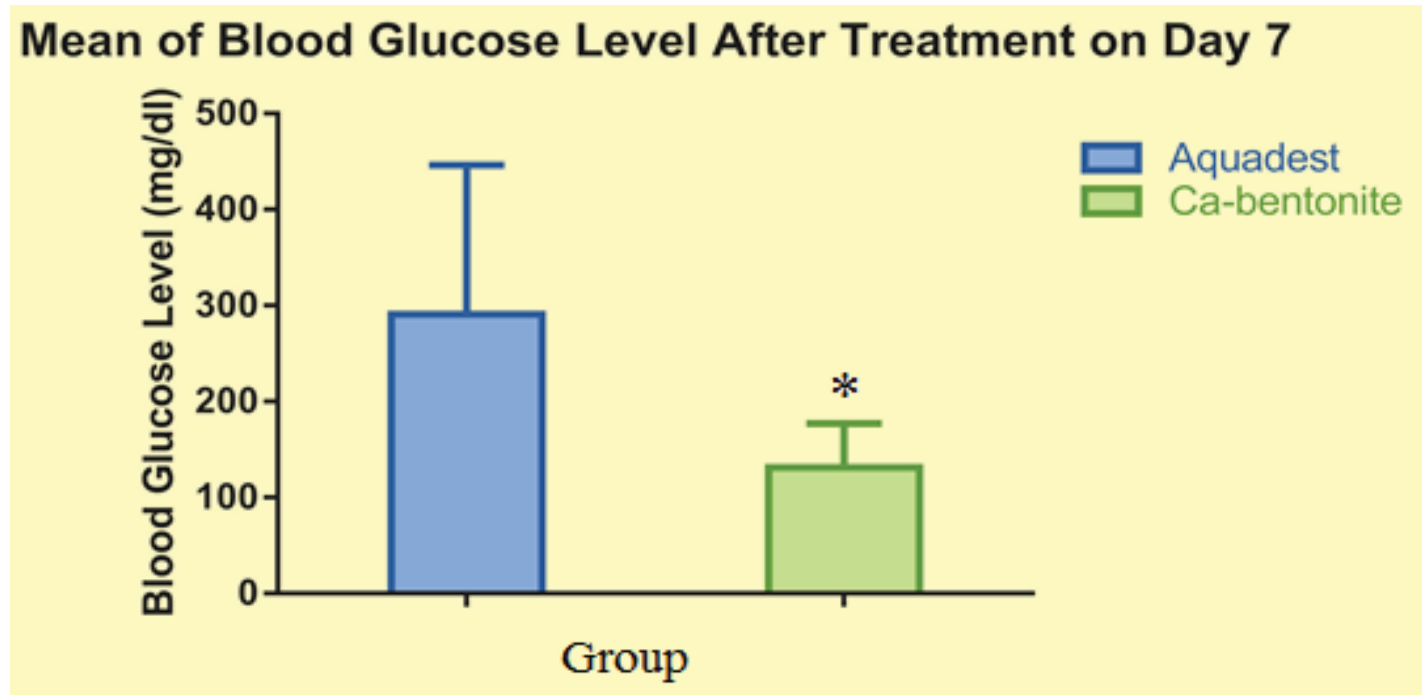

Figure 1 Blood glucose levels after treatment on day 7 (mean \pm SD) in alloxan monohydrateinduced diabetic Wistar rat treated with $1 \mathrm{~g} / \mathrm{kg}$ ca-bentonite $(\mathrm{n}=10)$ vs. aquadest as control $(n=10)$. 
induced diabetes in rats (Day 7). Aquadest group that acts as a control group also showed a significant decrease in the blood glucose level.

Table 1 shows that blood glucose levels in all groups were increased after induction of alloxan monohydrate (Day 3), then started to fall after the treatment was given (Day 7). Box-plots of mean blood glucose levels 4 days after treatment (Day 7) can be seen on Figure 1. From Figure 1, the group given ca-bentonite had the smallest mean of blood glucose level.

Data was compared to the control group and analyzed using t-independent test which showed that the data was statistically significance $(p=0.01)$ with mean of blood glucose level in ca-bentonite group was 131.30 $\mathrm{mg} / \mathrm{dl}$. This study has proved the effect of alloxan monohydrate to optimally induced diabetes mellitus three days after induction, after which the hyperglycemia state decreased after 3 days of treatment in both control and treatment groups.

\section{Discussions}

Management of diabetes with agents without any side effects is still a challenge. This concern has led to an increase and demand for natural products with anti-hyperglycemic activity.

Alloxan monohydrate as the diabetesinducing agent was known to produce diabetes mellitus irreversibly with a single dose administration through its ability to destroy the beta cells of the pancreas leading to insulin deficiency. Several in vitro studies have shown that alloxan monohydrate is selectively toxic to pancreatic beta cells mediated by reactive oxygen species, leading to the induction of cell necrosis. $^{8}$

This experimental study revealed that the local ca-bentonite orally administrated for three days produced a significant decrease in the blood glucose level in the model of alloxan monohydrate-induced diabetes in rats. Cabentonite is known as a good absorbent and adsorbent, and has been proven in vitro..$^{10-11}$

The in vivo mechanism of blood glucose reduction after administration of ca-bentonite is based on its good absorption and adsorption capacity. In intestinal lumen, ca-bentonite will absorb the glucose without getting into the bloodstream. This mechanism is similar to ca-bentonite in reducing blood ureum and creatinine in acute renal failure occurred in Wistar rats, and high cholesterol level of highly fat diet Wistar rats from previous studies..$^{3-6,12}$

Further studies should be performed to confirm that ca-bentonite could become useful in the treatment of diabetes mellitus through its unique therapeutic mechanism without any side effects. In conclusion, ca-bentonite significantly lowers blood glucose levels.

\section{References}

1. Eaton JR. Healing clays of the world bentonite as used in pelotherapy, natural and alternative medicine. Las Vegas: AVRA; 2004 [Cited 2012 May 13]; Available from: http://www.eytonsearth.org/ introduction-clays.php.

2. Eaton JR. Green healing clay of the desert bentonite, illite, and montmorillonite: pelotherapy and natural medicine. Las Vegas: AVRA; 2004 [Cited 2012 May 13]; Available from: http://www.eytonsearth. org/.

3. Cao YX, Long LH, Ma Z, Tao XJ, Liu J, Zhou L. Effect of montmorillonite on diffussion of urea between blood and intestine and on absorption of intestine in rats. Zhong Yao Cai. 2009;32(2):249-53.

4. Gershkovich P, Darlington J, Sivak O, Constantinides PP, Wasan KM. Inhibition of intestinal absorption of cholesterol by surface-modified nanostructured aluminosilicate compounds. J Pharm Sci. 2009;98(7):2390-400.

5. Sivak O, Darlington J, Gershkovich $P$, Constantinides PP, Wasan KM. Protonated nanostructured aluminosilicate (NSAS) reduces plasma cholesterol concentrations and atherosclerotic lesions in Apolipoprotein E deficient mice fed a high cholesterol and high fat diet. Lipids Health Dis. 2009;8(1):30.

6. Gershkovich P, Sivak O, Contreras-Whitney S, Darlington JW, Wasan KM. Assessment of cholesterol absorption inhibitors nanostructured aluminosilicate and cholestyramine using in vitro lipolysis model. J Pharm Sci.2012;101(1):291-300.

7. Sunarsih ES, Djatmika, Nilawati S. Pengaruh infusa daun murbei (Morus alba L.) terhadap penurunan kadar glukosa darah tikus putih jantan diabetes karena pemberian aloksan. Trad Med J. 2007;12(40):1-6

8. Lenzen S. The mechanisms of alloxanand streptozotocin-induced diabetes. Diabetologia. 2008;51(2):216-26.

9. Sunarsih ES, Djatmika, Utomo RS. Pengaruh pemberian infusa umbi gadung (Dioscorea hispida Dennst) terhadap penurunan kadar glukosa darah tikus putih jantan 
diabetes yang diinduksi aloksan. Majalah Farmasi Indonesia. 2007;18(1):29-33.

10. Irineo Torres-Pacheco, editor. Comparative evaluation of different techniques for aflatoxindetoxification in poultry feed and its effect on broiler performance. Pakistan:InTech; 2011.

11. Lynch DL, Wright LM, Cotnoir LJ. The adsorption of carbohydrates and related compounds on clay minerals. Soil Sci Soc
Am J. 1956;20(1):6-9.

12. Kamalakkannan N, Prince PS. Antihyperglycaemic and antioxidant effect of rutin, a polyphenolic flavonoid, in streptozotocin-induced diabetic wistar rats. Basic Clin Pharmacol Toxicol. 2006;98(1):97-103. 